\title{
Managerial Evaluation Program on Non-Formal Education for Dropped-Out Teenagers
}

\author{
Supardi \\ Universitas Muhammadiyah Palangkaraya, Indonesia \\ *Corresponding Author: Supardi, Universitas Muhammadiyah Palangkaraya, Indonesia.
}

\begin{abstract}
This study aims to find out the results of evaluation on the implementation of Non-formal Education Program for dropped-out school teenager on components: instructional, institutional and behavioural assessment.

This research is an evaluation study with a qualitative method which aims to reveal phenomenon in the process of implementation of the program that takes place in the application of non formal education in Central Kalimantan Province, Indonesia. The research model design uses the Goal Oriented Approach Approach (GOA) developed by Robert Hammond.

The results show that the performance of the program reaches a value of "Good" in the area of organization, content, method, and facilities. However, the implementation only reaches "Satisfactory" in the field of administration and behavioural objects. This way treatment is required in the last two aspects of for improvement so that the quality of the implementation of the program in Palangkaraya city can achieve a better standard to meet the demanding needs of the community.
\end{abstract}

Keywords: Evaluation, Program Implementation, Non-formal Education.

\section{INTRODUCTION}

Education is an essential element of the national development process which is one of the decisive sources in a country's economic growth. In this context, education is seen as one form of investment (human investment). Teaching and training will improve performance because the welfare and wealth of a nation depend heavily on the intellectual superiority of the government.

Along with the attention to the importance of education, Central Kalimantan Governor's Vision continues to be directed to continue and complete the development of Central Kalimantan to make people more prosperous and dignified for the glory of the Unitary State of the Republic of Indonesia. Central Kalimantan Governor's mission is to create quality education accessibly.

Departing from the concerns and vision of Central Kalimantan in building Kalimantan Tengah Harati (Smart Central Kalimantan), the provincial government through social institution of Majar Tabela (Teaching the Youth). Local government's fund supports this program giving the opportunity for adolescent with all limitations experience education and learning process that is worthy and meaningful as the aspiration of Central Kalimantan and the Republic of Indonesia.

Central Kalimantan consists of 13 districts and one city, and it is estimated that the number of junior and senior high school dropouts is found in 25 areas. Thus, the total number of out-of-school children of Central Kalimantan Province aged 13-21 in 2014 is $25 \times 13$ regencies $=325$ people +50 people from the city, which is 375 people.

Evaluation is one of the entire management processes even as an activity that ends in a series of the directorate processes undertaken by an organization. The whole set of management activities that include planning, implementation, and evaluation each have its theory that will guide the mindset and pattern of individual acts personally within the organization as well as the group. With this consideration in mind, this article aims at evaluating the effectiveness of the program.

\section{LITERATURE REVIEW}

Limitation of the word "evaluation" according to Wirawan (2012) is a research evaluation to collect, analyze, and present useful information about the object of assessment, assessing and comparing the target assessment with evaluation indicators, and the results are used to make decisions about the object being evaluated. 
Vendung Evert (2009) says that the Evaluation is the process of determining the merit, worth, and value of things. In these expressions, it can be interpreted that the assessment is a process for setting benefits, price, and the value of something.

Birkland (2001) about public policy implementation revealed that: "Evaluation is the process of determining whether and to what extent a program is achieving some benefit explicitly or implicitly.

According to Stufflebeam and Chris Coryn (2014): "evaluation is the systematic assessment of the worth or merit of an object." Evaluation is an act of the assessment systematically to achieve the value and benefits of a particular purpose. Thus, the activities of the assessment of a program can be understood as an attempt to get the value and benefit to the desired target in the program. Stufflebeam and Coryn added that the evaluation activities related to the achievement of values such as effectiveness, efficiency, utility, finance, safety, legality, and so forth. Such activities should use the structured and tiered procedures.

Watson and Paul Noble (2007) said that: "the practice of evaluation involves the systematic collection of information about the activities, characteristics, and outcomes of programs, personnel, and products for concrete used by people to reduce uncertainties, improve effectiveness, and the make decisions regarding to what are reviewed on those programs, staff, or products doing and affecting. The emphasis of the evaluation was to carry out the improvement of the effectiveness of program performance. The assessment is the systematic measurement activities against a program, to get the facts that can be the raw material for the making of the decision, and seek to obtain the values of the results or benefits of the product of the program.

According to Jones, (2002) understanding of the work program is an activity that has obtained approval to achieve the goal. The program has certain characteristics that can help researchers to identify whether an activity can be considered as a program or not. Implementation of a program tends to require some executive staff in the field with the task to run programs already available. A program typically has its budget, which means that the evaluation of a program can also be identified through the available budget. The program also has its style that can run to obtain public recognition.

Langbein and Claire L. Felbinger (2006) say that: "programs are ongoing services or activities...that is intended to have ongoing, long-term effects, or goals, include the provision of social and other public services and the implementation of regulations designed to affect the behavior of individuals, business, or organization."

Measures to evaluate the program are considered to anticipate the number of climatic changes in society. In other terms related to the evaluation program terms, Langbein and Claire L. Felbinger (2006) says: "program evaluation is the application of empirical social science research methods to the process of judging the effectiveness of public policies, programs, or projects, as well as their management and implementation, for decision-making purposes. "

Madaus, and Daniel L. Stufflebeam (2002) defines the evaluation of the program as: "program evaluation means a study designed and conducted to assist some audience in assessing an object's merit and worth." Evaluating of the program is more emphasized on planning and implementation in measuring or assessing a performance of a program. The measurement or assessment seeks to get the benefits and values that can meet the demands of the interested parties, for the right of the service provider and the community.

When evaluating programs, this research is associated with professional standards used in Standard for Educational Evaluation to build a contribution for the improvement in the areas of learning, teaching, administration, health, and in general to improve quality of life.

\section{Data Collection}

Although many models of evaluation of the program used as a reference for the study the implementation of programs, such as the famous Context, Input, Process, and Product (CIPP), this research model chose the Goal Oriented Approach Approach (GOA) developed by Robert L Hammond (1967). This type is selected from among several other models because this model is compatible with the program flow theory. The model is starting from instruction evaluation which includes; first, the organization - the activity of the event, second, content to be discussed, third; methods to support processes designed to facilitate learning activities; fourth, learning facilities; fifth; cost required for teaching and learning facilities, and maintenance. The next step is institution 
evaluations restricted to nonformal education participating population members who are involved directly or indirectly act as a force affecting program outcomes; and finally behavior object evaluation including results of participants in understanding the material and applying learning outcomes through reading, writing, and arithmetic.

Data collection is done using narrative or verbal method that is through observation techniques, interviews, and document analysis. The data in qualitative research on nonformal education for drop out teenagers will be revealed as clearly and deeply as possible by the aspects of research that have been set out above.

\section{RESUlt AND Discussion}

\subsection{Components of Instruction Focus on the Problem}

$>$ The organizational aspects that include time, schedule, the sequence of lessons, and organizing that also focuses on the final result of the life skills that will be held by participants of nonformal education programs in Palangka Raya Central Kalimantan. Implementation of this organization is a process of applying ideas, concepts, policies, or innovations in a practical action to impact whether in the form of changes in knowledge, skills, and values, and attitudes. The researcher opines that the organization has been neatly and regularly arranged so at this stage falls under the category of satisfactory.

$>$ Content aspects have been known and understood by program participants. This content always refers to the initial ideas of the establishment of this institution as a social institution of youth development in Central Kalimantan as an integral part of the fulfillment of the necessities of life on the welfare of others who also get the same rights.

The targets of nonformal education programs are economically disadvantaged communities but retain their rights in the process of participation in lifelong education. The inability of a parent/guardian in providing care directly affects the child's developmental growth naturally. If this is not dealt with immediately, it is likely that children will be abandoned and drop out of school. This stage is under category Good.

$>$ In the aspect of the method, this context has clear program implementation procedures in support of nonformal education process for drop out teens. In this principle is how institutions provide and facilitate learning activities for program participants so that in the process participants of nonformal education programs achieve the primary objective of this program which is to help program participants to have a decent capacity in the following education.

In principle during the observations, the researcher finds at least the learning process which is to meet the competencies that have been established. Implementation of this program has a frame of reference or SOP that regulates the whole process and in outstanding criteria.

Institution component in program implementation aspect with an indicator of administration section is categorized satisfactory. Instructors/teaching staff cannot be fulfilled properly, so additional teachers and tutors are needed resulting in a less satisfactory category. Similarly, the presence of teachers in the field of expertise is not appropriate and categorized less satisfactory as well. On the aspect of program participants that include motivation to follow the plan and knowledge about the program objectives and rules during the program are categorized good.

The whole of this process of implementation in the view of the researcher has been well implemented. However, some evaluations is still limited to the experts who handle and do the coaching when compared with participants who follow the non formal education.

In Behavior Object evaluation, the overall success of non formal education programs is seen in the aspect of cognitive influence on how many participants who have long participated in this program have the ability to understand the material following predetermined criteria. In this indicator, the researcher obtained the value data from the test results that show that the program is good. In the affective domain index, the right attitude demonstrated by the participants of this non formal education program can be seen in the daily life of the program participants who showed good value. In psychomotor indicators, the application of learning outcomes in life is the most essential. Observations of the researchers show that success in this non formal education program on the criteria is satisfactory. 


\section{CONCLUSION}

Implementation of the non-formal education program for teens dropping out from school in Majar Tabela Palangka Raya in the component of instruction which includes organization, content, method, facilities, the cost of supporting the success of this learning shows good criteria.

Institution elements in the implementation of Non-formal Education program indicate that the administration in this non formal education activity is categorized satisfactory. Teachers who are involved in the learning process of non formal education program observed cannot be fulfilled properly so that the institution needs to get additional teaching staff and instructor. The presence of teachers who teach is also not appropriate expertise with the field of specialization in the program. This condition shows that in this indicator is less satisfactory.

Behavior object components indicate participants who join this program have the ability to understand the material per predetermined criteria. Observations of researchers as discussed above show success in this non formal education program on the standards of satisfactory.

\section{REFERENCES}

[1] Birkland, Thomas A., an Introduction to Policy Process: Theories, Concepts, and Models of Public Policy, Armonk, New York: M.E. Sharpe, 2001.

[2] Hammond, R. L. Evaluation at the Local Level. 1967.

[3] Jones, Charles O., Pengantar Kebijakan Publik, Terjemahan oleh Ricky Istamto, Jakarta: Raja Grafindo Persada, 2002.

[4] Langbein, Laura I., and Felbinger, Claire L., Public Program Evaluation: A Statistical Guide, Armonk, New York: M.E. Sharpe, Inc., 2006.

[5] Madaus, G.F., and Stufflebeam, Daniel L., Evaluation Models: Viewpoints on Educational and Human Services Evaluation, $2^{\text {nd }}$ Ed., Dordrectht: Kluwer Academic Publishers, 2002.

[6] Stufflebeam, Daniel L., Chris L.S. Coryn., Evaluation Theory, Models, and Applications, $2^{\text {nd }}$ Ed., JosseyBass, A Wiley Brand, San Fransisco, 2014.

[7] Vendung, Evert, Public Policy and Program Evaluation., USA: Transaction Publishers, Fourth Paperback Printing, 2009.

[8] Watson, tom., and Noble, Paul.,Evaluating Public Relations, London, UK: Kogan Page, 2007.

[9] Wirawan, Evaluasi: Teori, Model, Standard, Aplikasi, dan Profesi, Depok: Rajagrafindo Persada, 2012.

\section{AUTHOR'S BIOGRAPHY}

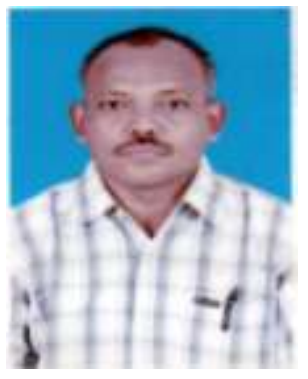

Supardi, born in Sidoarjo, February 24, 1964. Graduated from Senior High School in Palangka Raya in 1984 and graduated from Mathematics Education at Palangka Raya University (UNPAR) in 1991. In 1992 he was appointed as lecturer of at Muhammadiyah University of Palangka Raya. Completed master degree in Research and Evaluation of Education at Yogyakarta State University (UNY). Appointed as Vice Rector for Finance and Treasurer of Muhammadiyah University of Palangkaraya in 1992 - 1997. As Head of Research and Community Service Institute (LP3M) Muhammadiyah University of Palangkaraya year 1999 - 2010. Year 2010 - 2011 as Vice Rector of Academic Affairs. Year 2011 - 2015 as Vice Rector of Academic Affairs and 2015 - 2019 as Vice Rector for Human Resources, Administration and Finance.

Citation: Supardi, Managerial Evaluation Program on Non-Formal Education for Dropped-Out Teenagers. International Journal of Managerial Studies and Research (IJMSR), vol 5, no. 9, 2017, pp. 1-4.doi:http:// dx.doi.org/10.20431/2349-0349.0509001

Copyright: (C) 2017 Authors. This is an open-access article distributed under the terms of the Creative Commons Attribution License, which permits unrestricted use, distribution, and reproduction in any medium, provided the original author and source are credited. 